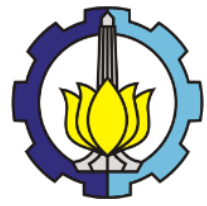

$8^{\text {th }}$ International Conference on

Architecture Research and Design (AR+DC)

November 1-2, 2016

\title{
Vernacular buildings as tourism asset in Eastern Indonesia
}

\author{
Titien Saraswati ${ }^{\mathrm{a}}$ \\ ${ }^{a}$ Duta Wacana Christian University, Jl. dr. Wahidin Sudirohusodo 5-25, Yogyakarta 55224, Indonesia \\ *Corresponding author. Tel.: +62 81228676546; fax: +62 274513235. \\ E-mail address: titiens@staff.ukdw.ac.id
}

\begin{abstract}
Indonesia has many traditional or vernacular buildings that still exist right now. Those buildings have already functioned partly as tourism asset in their areas, but so many vernacular buildings remain untouchable. Whereas, in the context of tourism, there is cultural heritage which consists of three main components: (1) monuments, (2) architecture or buildings, (3) sites. When we look at vernacular buildings in Eastern Indonesia, the possibilities those buildings to be tourism asset are high. The question should be explored is: what kind of potencies that can be explored, and in turn can be "sold" as tourism asset for vernacular buildings in the villages in Eastern Indonesia? The objective of this paper is to investigate the potencies of cultural heritage from which have possibilities to be tourism asset in several vernacular spots in Eastern Indonesia: Bayan Village (Lombok), Nua One small village in Woloara Village, Sikka and Mbengu Villages (Flores), Boti and Maslete Villages (Timor). Methods to collect data by surveying on the spot to vernacular buildings in the above locations, also surveying related and competent persons. Method to analyse the data by examining the data with tourism theories. The finding is, the potencies of vernacular buildings that can be categorized as the asset of tourism in the above villages are so many, which are architectural styles and cultural festivals in the villages, and also include the approach such as rehabilitation, renovation, restoration, and conservation.
\end{abstract}

Keywords: Tourism; vernacular buildings; fixed elements; cultural heritage; cultural attractions.

\section{Introduction}

There are many vernacular buildings which are in original forms in Eastern Indonesia. These vernacular buildings never be thought as tourism asset. Further, on our gathering on 2014 in Ende, Flores Island; the Head of the Indonesian Tourism Institution of Ende said that tourism prospect in Ende was not good. Whereas, according to me, there are several vernacular buildings there that can be functioned as tourism asset. It is also highly possibly that the situation and condition in the other areas in Eastern Indonesia are the same. They cannot see and realize that vernacular buildings there can be a great tourism asset.

\section{Research theories and methods}

According to (Nuryanti, 2009), the word heritage on the broad context is related to the word inheritance, that is something transferred from generation to generation. As the carrier of historic values in the past, heritage can be seen as a part of cultural tradition of the community. On the other side, tourism is a dynamic concept which is involving something that relatively new. Therefore, in the context of tourism, there will be a debate in the community between cultural tradition and modernity. 
The meaning of the words built heritage is complicated. These words are related to buildings preservation or historic monuments for a long time, but the use of these words in tourism recently is relatively new. With the emphasis to tourism, the word heritage has been used in the cultural and natural context. In the cultural context, the word heritage is used to describe monument, historic or architectural remains, and artifacts displayed in the museum.

Built heritage can be said very often as one of cultural heritage. As stated in the United Nations World Heritage Convention Concerning Protection of the World Cultural and Natural Heritage according to (Hewison, 1989; Ross, 1991), there are 3 (three) main components: (1) monuments, (2) building groups or architecture, and (3) sites. Built heritage, in which the basic process is archeological or architectural, is created from any of these: fixed, semi fix, and non fixed elements according to (Rapoport, 1982). Fixed element is rarely changed or the change is very slow, but it is organized and structured such as building, city, and ruins. Semi fixed elements can be moved easily, such as furniture and plant. Non-fixed element is related to human occupation to the place. Therefore, built heritage should not be separated from the object or other tourism asset in that place.

Furthermore, the above explanation can be inferred that one form of cultural heritage - that is built heritage - which it's basic process archeological or architectural, consists of monument, building or architecture, and site (all are the fixed elements) which are the results from the past and transferred from generation to generation; which its role as the carrier of historic values in the past, can be seen as a part of cultural tradition of the community in that area.

According to Lew (1987) in (Inskeep, 1991), tourist attractions can be categorized in various ways, and a common system of classification is to establish the major categories of: (1) Natural attractions that are based on features of the natural environment, (2) Cultural attractions that are based on man's activities, (3) Special types of attractions that are artificially created. From these three major categories, the category of cultural attractions is much more related to this study. Many types of cultural attractions, based on man's activities, include the following: (a) Archaeological, historical, and cultural sites, (b) Distinctive cultural patterns, (c) Arts and handicrafts, (d) Interesting economic activities, (e) Interesting urban areas, (f) Museums and other cultural activities, (g) Cultural festivals, (h) Friendliness of residents. From these types, the ones that much more related to this study are number (c) and number (g). Accordingly, Lew (1987) in (Inskeep, 1991) mentions that number (c) Arts and handicrafts, as in the following: related to arts and handicrafts are the traditional or distinctive architectural styles of an area that can be much interest to tourists, such as traditional architectural styles in Southeast Asia. Furthermore, number (g) Cultural festivals are various types of cultural festivals related to local traditions and arts that can be major attractions.

In addition, according to Direktorat Jenderal Pariwisata of Indonesia (Directorate General of Tourism in the Ministry of Tourism of Indonesia) together with Gadjah Mada University (Direktorat Jenderal Pariwisata, 1989), the approach the buildings or architecture should be categorized as tourism asset can be one or combination of the following concepts:

- Conservation: the act to keep the object physically or to maintain the activity of that place so that the meaning and the values can be kept.

- Gentrification: the act to enhance the physical vitality or activity on that place through enhancing the quality of the site with structural change.

- Rehabilitation: the act to bring back the condition of the building physically or the activity on that place on the damaged or lower quality of the area.

- Renovation: the act to change the object physically and also activity on that place in order to adapt or accommodate a new function; or to adapt the old one to the new need through adaptive re-use concept.

- Restoration: the act to improve physical condition and activity on that place through removing new things or elements already added; and adding the vanished, original elements in order to bring back to the original setting.

- Reconstruction: the act to bring back physical condition and activity on that place as much as possible to be the same with past condition. 
Therefore, from the evaluation of built heritage above which its basic process is archeological or architectural, it can be known the approach that will be used to decide the object as tourism asset; whether will use one or combination of the above concepts.

Methods for collecting data by surveying on the spot to several vernacular buildings in Eastern Indonesia: Bayan Village (Lombok Island), Nua One small village in Woloara Village (Flores Island), Sikka and Mbengu Villages (Flores Island), Boti Village (Timor Island) and Maslete Village (Timor Island). The above surveys were the effort of the author to study and examine continuously to vernacular buildings. Additionally, surveying to institution and related persons were conducted. Methods to analyse the data by examining the data to tourism theories.

\section{Results and discussion}

In the following are the results of survey on the spot that conducted, to repeat, in Bayan Village (November 2014, Lombok Island), Nua One small village in Woloara Village (November 2014, Flores Island), Sikka and Mbengu Villages (December 2011, Flores Island), Boti Village (August 2013, Timor Island) and Maslete Village (December 2012,Timor Island). Here are the maps showing the location of each villages aforementioned on corresponding islands (Fig. 1 and Fig. 2).

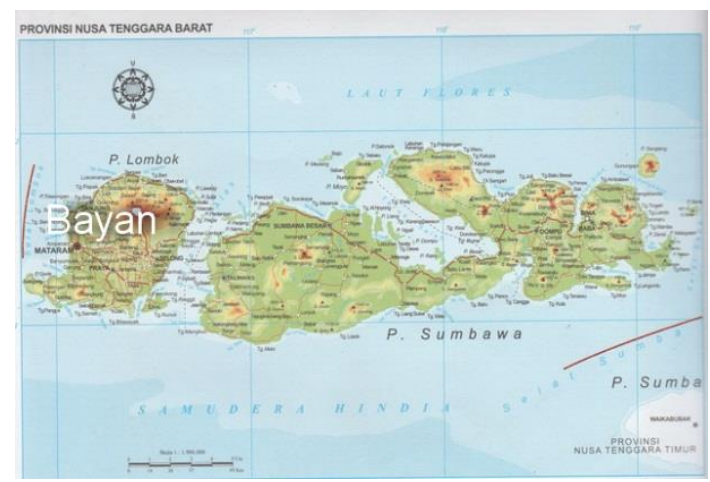

Fig. 1. Map of Lombok Island.

Source: (Suhardiman, 2008).

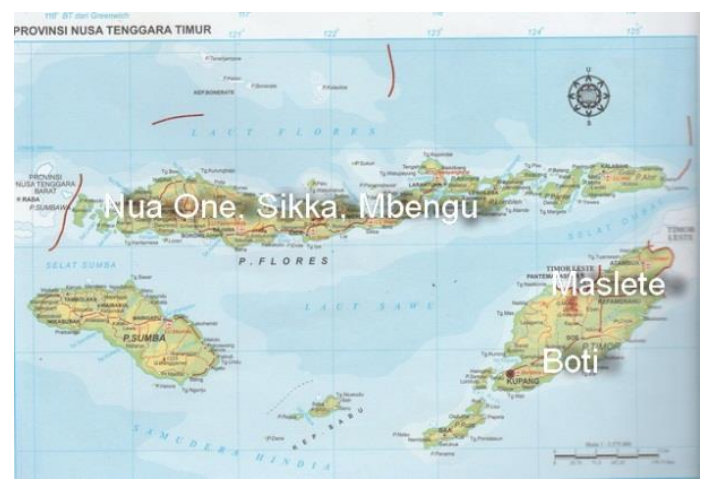

Fig. 2. Map of Flores Island and Timor Island. Source: (Suhardiman, 2008).

\subsection{Bayan Village, Lombok Island}

Bayan Village located at North Lombok Regency, at the hill of Rinjani Volcano, about 75 kilometers from the city of Mataram. This village located right on the main road in Lombok, and easily accessible. This village still holds its old tradition very strictly, such as its vernacular buildings, and the way of life of the people.

Vernacular buildings there have the roof from grasses (alang-alang), the wall made of woven bamboo (Fig.3). The ground inside still be kept as the material for flooring. Local people just rammed down the soil for flooring. The traditional rulers of the community in this village stay at Kampu area, an area that is restricted to ordinary people, and demarcated by fences. But the tourists are allowed to enter Kampu area. This indicates that there is a "new" activity that is permitted by traditional community. This condition is matched to the concept of renovation.

There is also Bayan Beleq Mosque, an oldest mosque in Lombok (Fig. 4), built about hundreds years ago when the Islam religion reached Lombok. Even though this mosque has already rehabilitated so many times, but the original form and the material of the buildings still be kept as same as long time ago. 


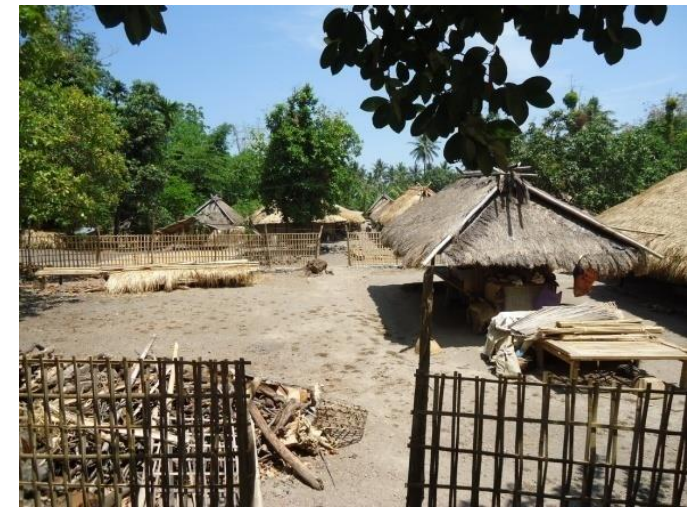

Fig. 3. Bayan Village, occupied by Bayan ethnic. Source: Author's Documentation, 2014.

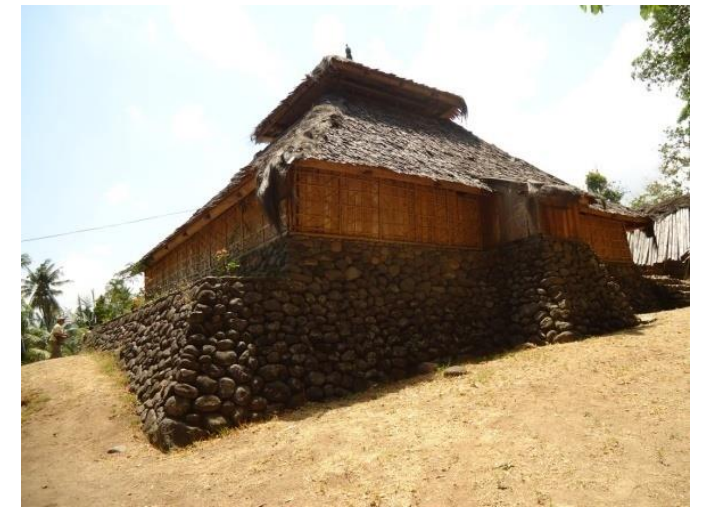

Fig. 4. Bayan Beleq Mosque, the oldest mosque in Lombok. Source: Author's Documentation, 2014.

The wall is made of woven bamboo, the roof from the bamboo plates (bilah bamboo), the floor from the ground soil that is erected on stone foundations. The plan is square, about $10 \times 10$ meters, and the height of the wall only 1.50 meters, no windows, so that inside the mosque is dark. Artificial lighting inside is obor, from dried grasses or fabrics that ignited by fuel or petroleum.

Even though this village has already been visited by tourists, but it seems not optimum. Possibly because there is no socialization, or not supported by local government; in spite the fact that the accessibility to go there is very easy and clear. It is the traditional or distinctive architectural styles that attract tourists to visit these vernacular buildings, as Lew (1987) mentions in (Inskeep, 1991). It can be inferred that the approach to be tourism asset can be done by two ways: rehabilitation of Bayan Beleq Mosque and renovation of vernacular houses in this village.

\subsection{Sikka Village, Flores Island}

Sikka village is located at Lela District, Sikka Regency, and the city of Maumere is the capital of Sikka Regency. Maumere is the homeland of Sikka people with their Sikka language. The other ethnics who also reside in Sikka Regency are Lio, Palu, and Chinese.

Before Sikka Regency was established in 1958, according to (Kondi \& Pareira, 2008), Sikka community was ruled by the King of Sikka who resided at building named Lepo Gete (Fig. 5, Fig. 6), means big house or palace. The Kings of Sikka ruled in the $16^{\text {th }}$ century when this area was occupied by Portuguese, and in the $17^{\text {th }}$ century when the Dutch occupied this area. Lepo Gete is right on the seashore of Sawu Sea.

Lepo Gete contains of three bedrooms for the family of the King of Sikka, one living room for the guests, and a corridor that connects the front and the back of this building. The building is raised structure, constructed from wood, the roof from grasses (alang-alang). This building is now vacant, but is used by local fishermen to stay temporarily and as the place for repairing the net for catching fishes. No ones nor descendants of the King of Sikka now are willing to stay there.

The original columns were from the trunks of coconut trees that were erected on stone foundations. Now this stones foundations were changed to concrete foundations, and the columns also were changed to wooden columns. Of course the size of columns is smaller than that of original columns. There are stepladders to enter Lepo Gete, from both front and back of the building. The original stepladders were constructed from wood, but now the east stepladders were changed to concrete ones because concrete stepladders are stronger and easier to maintain than those of woods. 


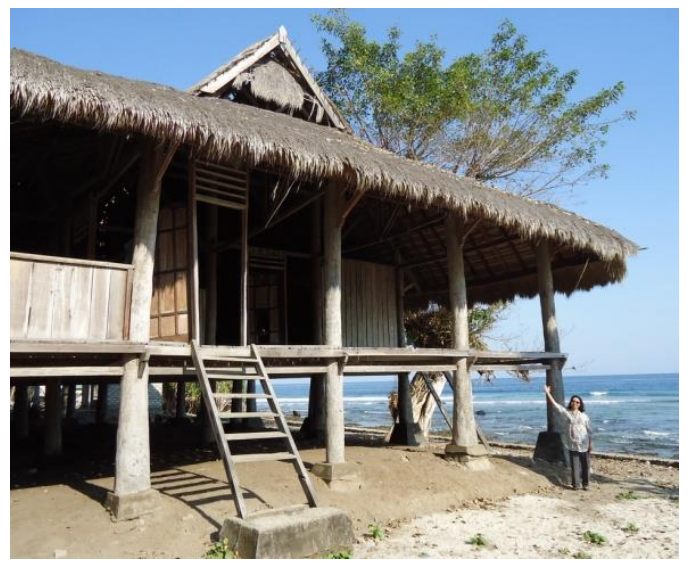

Fig. 5. Lepo Gete, right on the bank of Sawu Sea.

Source: Author's Documentation, 2011.

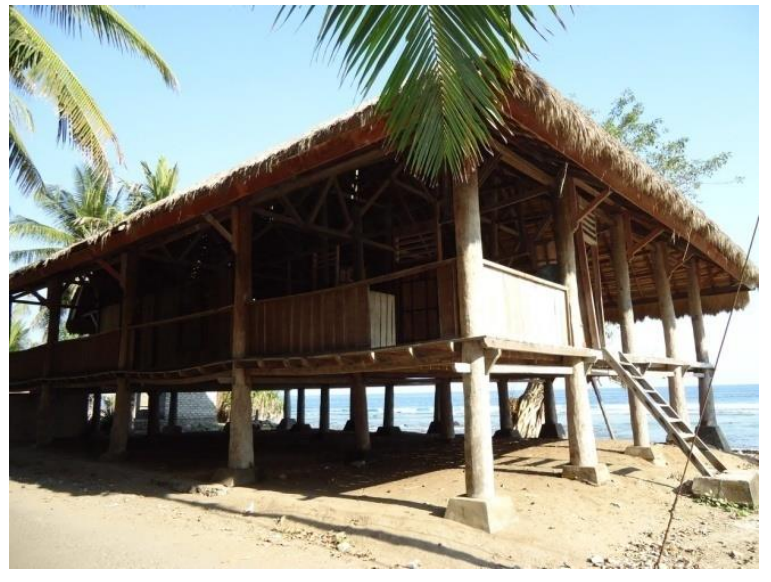

Fig. 6. The length side of Lepo Gete.

Source: Author's Documentation, 2011.

According to one of the descendant of the King of Sikka (Bapak Oretis Pareira), the structure of Lepo Gete building now is not as strong as that before the reconstruction in 2002 took place. Furthermore, the community of Sikka village were disappointed by the government (Pemda Kabupaten Sikka) because the budget to renovate Lepo Gete was used to other activity by the government.

In turn, renovation of this building only spent half of the total budget for renovation. So that the building materials used for renovation were not the same as those in the past. But Lepo Gete still holds its vernacular qualities, such as: the form and much of the materials of the building still the same as those in the past even though the wooden stepladders were changed to concrete stepladders. Structural elements still use local building materials.

Lepo Gete has very much potencies to be tourism asset, because of its location and its accessibility. Located right in the seashore, very much near the Sawu Sea, it is also accessible 2-3 minutes walking from the Old Church complex that is also one of tourism destination in this area. On the other side, the budget for maintaining Lepo Gete is the problem. One thing that should be done is, the seriousness of the Regency of Sikka to provide budget for renovation. Whereas, according to Lew (1987) in (Inskeep, 1991), it is the traditional or distinctive architectural styles that attract tourists to visit the vernacular buildings. It can be inferred that the approach to be tourism asset for Lepo Gete can be done by rehabilitation and restoration.

\subsection{Mbengu Village, Flores Island}

This village is located in Paga District, Sikka Regency. The site is a cemetery complex of the descendants of the King of Paga. Lepa Ria Kunu Mbengu (Fig. 7, Fig. 8) is a vernacular, main building in this site, it is a cult house. According to the owner of this building, one of the descendant of the King of Paga (Bapak Yohannes Brechmans), this Lepa Ria building is still used to be his house, and also to be a place for ritual ceremonies and gathering for the community. When the community would like to talk about a problem, they will gather in this building. For example, to talk about the landsite, law, election of the head of the community, specific ritual, and so on; that is leaded by the head of traditional community (Ria Bewa).

This Lepa Ria Kunu Mbengu is owned and occupied, to repeat, by one of the descendant of the King of Paga. There are 1 kitchen, 2 bedrooms, and 1 room to keep kitchen utensils (mugs, mangkuk) that made of stone. These kitchen utensils to be used when there is a ritual ceremony. Not only a ritual ceremony takes place in this building, but also punishment takes place inside too. Even though the police (of Sikka Regency) has already punished the suspected person, but the traditional law (convention) in this place is the primary to follow. 


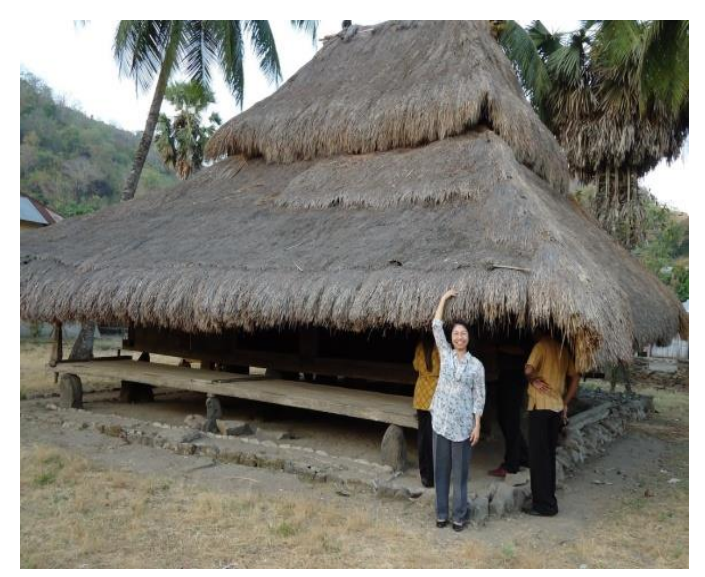

Fig. 7. Lepa Ria Kunu Mbengu seen from the front side. Source: Author's Documentation, 2011.

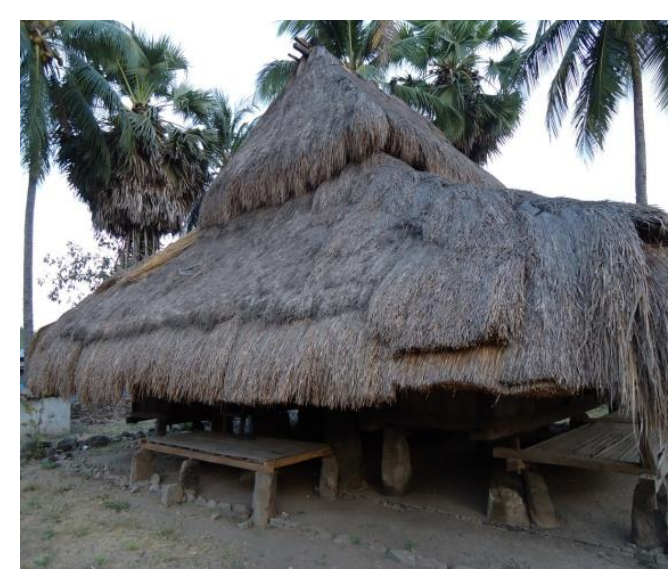

Fig. 8. The back side of Lepa Ria Kunu Mbengu.

Source: Author's Documentation, 2011.

One thing is differing this Lepa Ria Kunu Mbengu building with the other buildings in this site: there are "columns" stand up on the land but never continue to the roof after reaching the floor (the floor made of wood). The roof is thatched by grasses (alang-alang). The lowest part of the roof on the front of the building is lower than that on the back of the building. So the person who would like to enter this building should bow his/her body, means to give respect to this building. Some of the buildings in this site have already changed the roofing from grasses to zinc because of the difficulties to find grasses nowadays. Lepa Ria Kunu Mbengu is never changed, remain the same as in the past, like vernacular building hundred years ago.

Lepa Ria Kunu Mbengu has the potency to be tourism asset because of the uniqueness of this building, as Lew (1987) in (Inskeep, 1991) mentions. Accessibility to go there is very easy, because there is Paga beach which also one of tourist destination. The tourists should be guided to visit this Lepa Ria Kunu Mbengu and its complex. So that the approach to be a tourism asset can be done with 2 ways: rehabilitation of Lepa Ria Kunu Mbengu and renovation of this traditional village.

\subsection{Nua One small village, Flores Island}

Nua One small village is located in Woloara Village, Kelimutu District, Ende Regency. The time the author came there in November 2014, was the time when ritual ceremony of topping off one of vernacular building of Lio ethnic took place. The building was Sao Ria Tenda Bewa, means big house. This new building was erected with financial budget provided by Tirto Utomo Foundation from Jakarta. Accordingly, the name of this building was Sao Ria Tenda Bewa Tirto Dolu Ranggo. Topping off of the building means erecting the highest structure of the building, with the help of architecture students from Flores University, Ende (Fig. 9).

Even though this Sao Ria Tenda Bewa building is the new one, but the character of vernacular building is very clear. The form of the building is loyal to the form of local building, the materials of the building also from local materials. Ritual ceremony began to take place with performing traditional dances by local women welcoming the guests, and the guests should wear traditional customs too. Then erecting the highest structure of roofing that was done by local people and volunteers (architects and architecture students). While the men erected the highest roofing, the women provided the food for the ceremony by cooking together near this site of Sao Ria Tenda Bewa. 


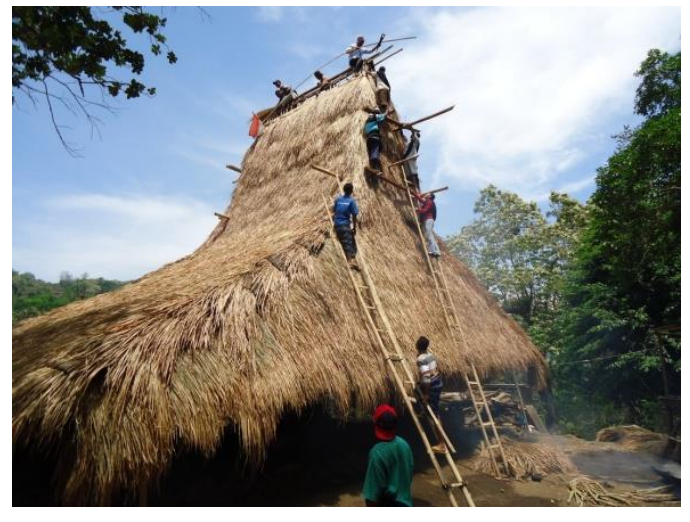

Fig. 9. Toping-off the highest part of Sao Ria Source: Author's Documentation, 2014.

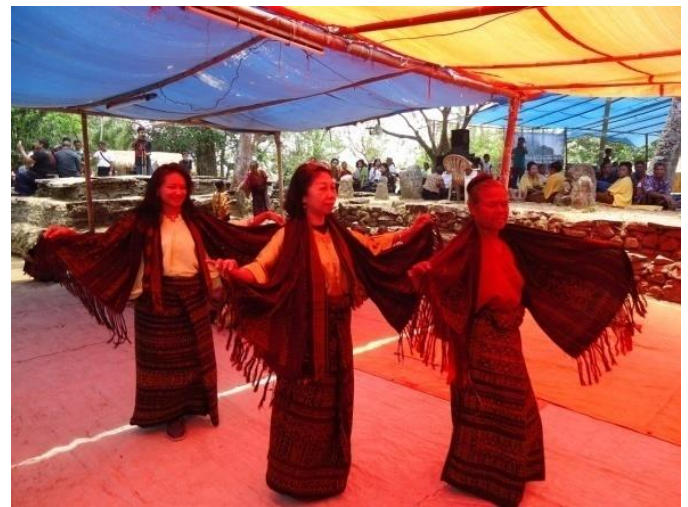

Fig. 10. Ttraditional dance, involving the guests.

Source: Author's Documentation, 2012.

According to Lew (1987) in (Inskeep, 1991), one of cultural attraction that can be categorized as tourism asset is cultural festival, which relates to local tradition that can be a main attraction in the place. This is very much in accordance with ritual ceremony of topping off Sao Ria Tenda Bewa building and its activities provided at Nua One small village. When erecting the highest structure of roofing was over, then followed by cheerful, enthusiastic dances where the guests also allowed to participate dancing together with local people (Fig. 10).

Then followed by consuming lunch together all local people and the guests. This ritual ceremony was also attended by special invited guests, the Regent of Ende and his staffs. He officially legalized Sao Ria Tenda Bewa new building which formally done inside this building.

All ritual ceremonies and activities related to Sao Ria Tenda Bewa were very much followed enthusiastically by all persons there, whether local people or the guests, and took place all day long. So it is possible that these ceremonies can be tourism asset. While exhibiting cultural festival (dances, cooking together, lunch together), these ceremonies also demonstrating the way to erecting the highest part or topping off of this unique building. So that the approach to all ceremonies and activities there to be tourism asset by conservation of all vernacular buildings there and the whole small village.

\subsection{Boti Village, Timor Island}

Boti Village occupied by Boti tribe, the oldest ancient, indigenous tribe in Timor Island. Located in remote area of hilly village in Ke'i District, about 40 kilometers from the town of SoE, the capital town of Middle-South Timor Regency, Timor Island. The way to go there is passing through gravelly, stony land. The people there have their own "religion", namely Halaika, that can be categorized "animism".

According to Halaika belief, when an adult man would like to marry, he has to built one Lopo and one Ume Kbubu, in which the Lopo (Fig. 11) and Ume Kbubu (Fig. 12) are categorized vernacular buildings as (T Saraswati, 2013) concludes. The location of the Lopo and Ume Kbubu should be built on the land owned by the adult man's parents. The land is divided by the number of the sons the parents have. The King of Boti holds this Halaika very strictly. In addition, the materials of the buildings are local materials, such as wood, grasses, gewang leaves, the trunks of gewang trees, and stone piles. From these materials of the buildings, it shows that the buildings are still categorized vernacular buildings. 


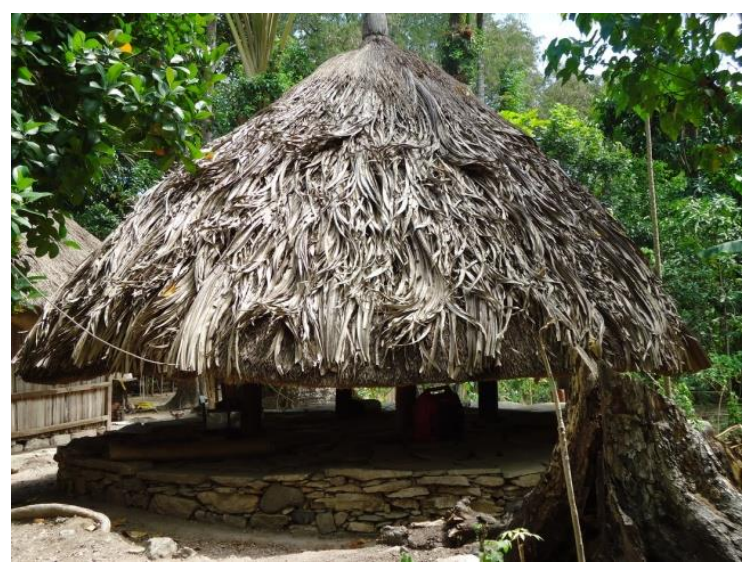

Fig. 11. Lopo, the roof is thatched by gewang leaves. Source: Author's Documentation, 2013.

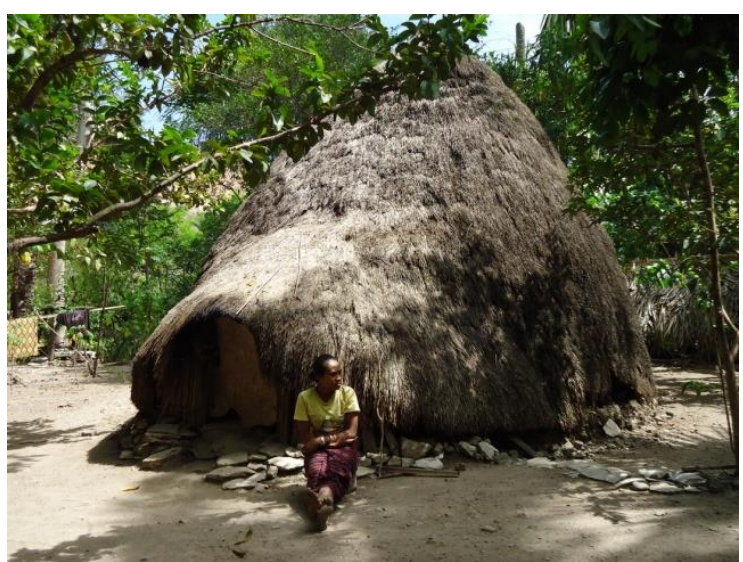

Fig. 12. Ume Kbubu, the roof is thatched by grasses. Source: Author's Documentation, 2013.

Nowadays there are buildings with new functions in Boti village (homestay, PKK office) which use "foreign" materials partly, such as masonry, cement, zinc. But this condition is only about $1 \%$ of the total vernacular buildings there. Furthermore, there is the role of the government/the regency to enhance the way of life of Boti people to be a better one. The PKK office has the advantages to Boti people. Here in this PKK office building, Boti women are trained by the government's official to have a better life in rearing their families and better income when possible, such as receiving guests to stay there. The guests who stay in homestay should pay the rooms and the food and the dances that danced by local people.

Actually this village already visited by the guests, from domestic and foreign people. Of course the existence of traditional regulation and the role of the King of Boti to urge his people to follow this regulation very strictly have effect in keeping and maintaining vernacular buildings and the environment. These distinctive architectural styles and the dances attract the guests (researchers, tourists) to visit, as mentions by Lew (1987) in (Inskeep, 1991). Plus, the role of the government in training Boti people, so that the approach to be tourism asset can be done by conservation of Lopo and Ume Kbubu buildings together with the environment.

\subsection{Maslete Village, Timor Island}

This village or Maslete traditional village located in Middle-North Timor Regency, about 17 kilometers from the main road of Kefamenanu town. The way to go there is passing through the gravelly, stony land too, but a bit better than that to Boti Village. Maslete Village is ruled by a King called Usif. Vernacular buildings there are Lopo and Sonaf.

Lopo or Ume Lopo means a building for people to gather, the same as that in Boti Village. But in Maslete Village, the Lopo (Fig. 13) is bigger than that in Boti Village, because the Lopo in Maslete Village resides inside the complex of traditional village occupied by the King of Maslete. Whereas the Lopo located outside this traditional village - for ordinary people - is smaller in size. The columns of the Lopo are decorated or crafting, the same for Sonaf, the other vernacular one.

Sonaf is located inside the complex of traditional village occupied by the King of Maslete and his families, or outside the complex that occupied by ordinary people but smaller in size. Of course the Sonaf (Fig. 14) which is inside the complex owned by the King is bigger in size than that owned by ordinary people. The plan of Sonaf is ellipse. The main activities inside Sonaf is for spiritual and traditional ceremony. The form of the roof is conical or saddle roof, as the results of the plan and trusses, but is sphere-shaped at its length side. The lowest part of the roof about $0.70-1.00$ meter from the land. So when the people would like to enter Sonaf, they should bow their bodies. 


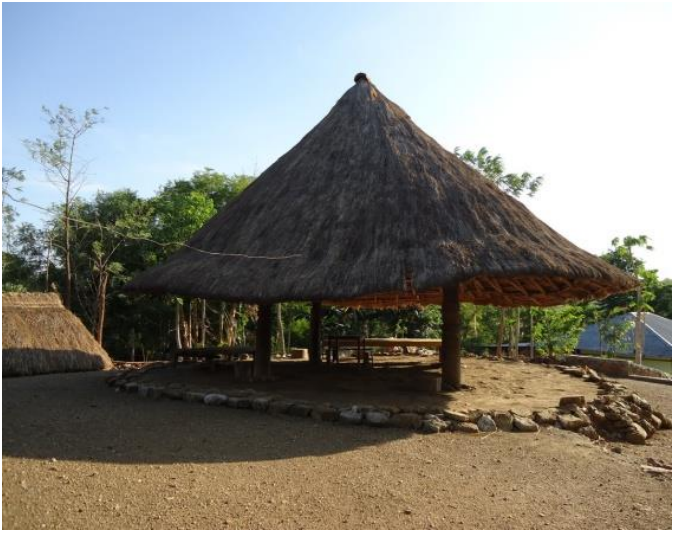

Fig. 13. Big Lopo in Maslete Village, owned by the King. Source: Author's Documentation, 2012.

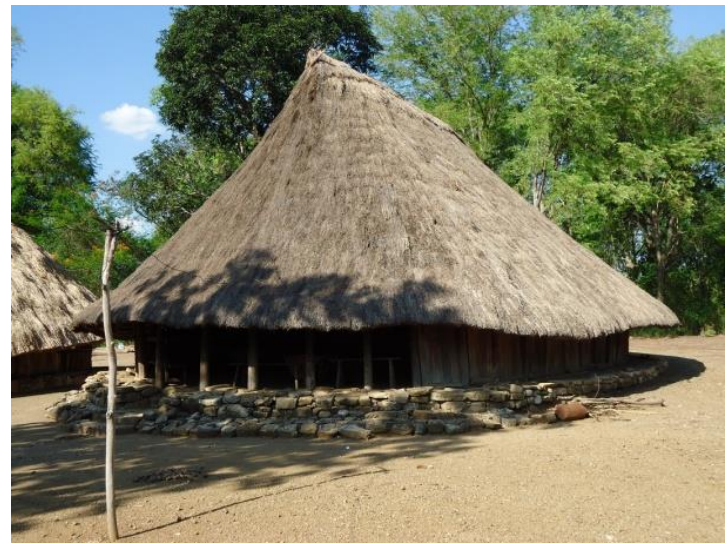

Fig. 14. Sonaf, owned by the King.

Source: Author's Documentation, 2012.

Sonaf has decoration and ornaments, crafted at its columns or part of the trusses. These decoration and ornaments display the people's cultural and traditional beliefs. Such as ornaments of head of human or heads of the birds at the lower parts of the trusses, ornaments of pot at the middle and lower parts of the columns, as mentioned in (Titien Saraswati, 2106).

The Lopo and Sonaf in this Maslete Village have a bit difference from the Lopo and Ume Kbubu in Boti Village. The ones in Maslete Village are much more various in decorations whereas the ones in Boti Village are very simple or have not been decorated.

These distinctive architectural styles of course will attract people to visit, as Lew (1987) in (Inskeep, 1991) mentions. The approach to be tourism asset in Maslete Village can be done by: conservation to Lopo and Sonaf, including its traditional site.

\section{Conclusion}

From the above discussion, it can be inferred that the potencies of tourism asset through the architecture of the six villages already discussed are possible within their cultural heritage. And the approach to be tourism asset can be done according to the condition of vernacular buildings above. So that it can be concluded in the following table:

Table 1. Tourism asset and the approach.

\begin{tabular}{|c|c|c|c|}
\hline \multirow[t]{2}{*}{ Cultural heritage } & \multicolumn{2}{|c|}{ Cultural attractions } & \multirow[t]{2}{*}{ The approach } \\
\hline & Distinctive Architect. Styles & Cultural Festival & \\
\hline \multirow[t]{2}{*}{ Bayan Village, Lombok } & Bayan Beleq Mosque & & Rehabilitation \\
\hline & Vernacular houses & & Renovation \\
\hline \multirow[t]{2}{*}{ Sikka Village, Flores } & Lepo Gete & & Rehabilitation, \\
\hline & & & Restoration \\
\hline \multirow[t]{2}{*}{ Mbengu Village, Flores } & Lepa Ria Kunu Mbengu & & Rehabilitation \\
\hline & Traditional village & & Renovation \\
\hline Nua One small village,Flores & Sao Ria & Ritual ceremony, dances & Conservation \\
\hline
\end{tabular}

$\rightarrow$ (Continued on the next page) 
$\rightarrow$ (Continuance from previous page)

\begin{tabular}{ll|ll}
\hline \multirow{2}{*}{ Cultural heritage } & \multicolumn{2}{c}{ Cultural attractions } & The approach \\
\cline { 2 - 3 } & \multicolumn{1}{c}{ Distinctive Architect. Styles } & \multicolumn{1}{c}{ Cultural Festival } \\
\hline Boti Village, Timor & Lopo, Ume Kbubu & Dances & Conservation \\
Maslete Village, Timor & Lopo, Sonaf & Conservation \\
\hline
\end{tabular}

Source: Author's Analysis, 2016.

While cultural attractions (distinctive architectural styles and cultural festivals) have already been known as in the above table, the approach to be tourism asset (whether one or combination of rehabilitation, renovation, restoration, or conservation) still be in questions how these could work or what the challenges for each approach, and so on. These should be done for further research.

\section{Acknowledgment}

The author would like to thank to all persons who accompanied the author to conduct field survey: the friends from Architecture Department University of Nusa Cendana, Kupang, Timor; the friends from Architecture Department University of Flores, Ende, Flores; the friends of RKO Group; and my architecture students from Duta Wacana Christian University. Without them, it would have been impossible for the author to have conducted the study.

\section{References}

Direktorat Jenderal Pariwisata. (1989). Pengembangan Keraton Surakarta sebagai pusat kebudayaan dan pariwisata. Jakarta: Direktorat Jenderal Pariwisata.

Hewison, R. (1989). Heritage: an interpretation. In Heritage Interpretation (pp. 15-24). London: Belhaven Press.

Inskeep, E. (1991). Tourism planning : an integrated and sustainable development approach. New York: Van Nostrand Reinhold.

Kondi, D. D. P., \& Pareira, A. B. (2008). Hikayat Kerajaan Sikka : edisi gabungan dari dua tulisan tangan tentang sumber dan sejarah Kerajaan Sikka. (E. D. Lewis \& O. P. Mandalangi, Eds.). Maumere: Penerbit Ledalero.

Nuryanti, W. (2009). The Role Of Heritage Tourism In Community Planning and Development. Gadjah Mada University Press.

Rapoport, A. (1982). The meaning of the built environment : a nonverbal communication approach. Sage Publications.

Ross, M. (1991). Planning and the heritage : policy and procedures. London: E. \& F. N. Spon.

Saraswati, T. (2013). Perbedaan dan persamaan antara bangunan vernakular dan arsitektur tradisional di Nusantara. In Prosiding Seminar Nasional Reinterpretasi identitas Arsitektur Nusamntara. Denpasar: Udayana University Press.

Saraswati, T. (2106). Bangunan Adat Timor di Desa Maslete dan Desa Boti. Seri Bangunan Vernakular. Yogyakarta: K-Media.

Suhardiman, I. (2008). Atlas : ilmu pengetahuan sosial Indonesia \&amp; dunia. Jakarta: Indo Prima Sarana. 


\section{$8^{\text {th }}$ International Conference on Architecture Research and Design (AR+DC)}

November 1-2, 2016 